\title{
Paleovegetation and Paleoclimatic Changes in the Yukon at 6 ka BP
}

\author{
Les changements apportés à la paléovégétation et au \\ paléoclimat du Yukon à 6 ka BP \\ Paläovegetation und paläoklimatische Veränderungen im \\ Yukon um 6 ka v.u.Z.
}

\author{
Les C. Cwynar et Ray W. Spear
}

Volume 49, numéro 1, 1995

La paléogéographie et la paléoécologie d’il y a 6000 ans BP au Canada Paleogeography and Paleoecology of 6000 yr BP in Canada

URI : https://id.erudit.org/iderudit/033027ar

DOI : https://doi.org/10.7202/033027ar

Aller au sommaire du numéro

\section{Éditeur(s)}

Les Presses de l'Université de Montréal

\section{ISSN}

0705-7199 (imprimé)

1492-143X (numérique)

\section{Découvrir la revue}

Citer cet article

Cwynar, L. C. \& Spear, R. W. (1995). Paleovegetation and Paleoclimatic Changes in the Yukon at 6 ka BP. Géographie physique et Quaternaire, 49(1), 29-35. https://doi.org/10.7202/033027ar
Résumé de l'article

Les changements apportés à la paléovégétation et au paléoclimat du Yukon à 6 ka BP. Au Yukon, les changements environnementaux les plus récents se sont produits vers $6 \mathrm{ka}$. Dans les zones forestières du sud du Yukon, l'épinette noire (Picea mariana) et l'aulne crispé (Alnus crispa) ont vu leur population augmenter entre 6,5 et 6 ka dans la plupart des sites. Même dans la région semi-aride du sud-ouest du Yukon, ces espèces ont connu une augmentation, bien qu'elle se soit produite plus tard, soit vers 5,5 ka. Ces changements dans la végétation méridionale du Yukon signalent l'avènement de saisons végétatives plus fraîches et plus humides, c'est-à-dire des conditions plus mésiques. Dans la région du cours supérieur de la Blackstone River, au centre du Yukon, Ia végétation moderne se compose d'une toundra arbustive parsemée ça et là de colonies d'épinettes blanches (Picea glauca) et de rares épinettes noires. Les forêts ouvertes dominées par l'épinette blanche peuplaient la région jusqu'à 9,5 ka, mais entre 6,5 et 6 ka, l'épinette blanche a décliné au profit de l'épinette noire, en concomitance avec une augmentation de l'aulne crispé. Vers $5 \mathrm{ka}$, la végétation avait acquis son caractère moderne. Tout comme au sud, ces changements impliquent un refroidissement. Il existe moins d'indices quant à l'expansion de l'aulne et de l'épinette noire dans le nord du Yukon. Les deux espèces se sont répandues dans les zones forestières (toundra forestières) à 6 ka. Encore une fois, il dut y avoir refroidissement. Puisque l'épinette noire et l'aulne crispé étaient présents dans le Yukon bien avant $6 \mathrm{ka}$, on ne peut attribuer ces changements enregistrées par la végétation à des décalages migratoires.
Tous droits réservés @ Les Presses de l'Université de Montréal, 1995
Ce document est protégé par la loi sur le droit d'auteur. L'utilisation des services d'Érudit (y compris la reproduction) est assujettie à sa politique d'utilisation que vous pouvez consulter en ligne.

https://apropos.erudit.org/fr/usagers/politique-dutilisation/ 


\section{PALEOVEGETATION AND PALEOCLIMATIC CHANGES IN THE YUKON AT 6 KA BP}

Les C. CWYNAR, and Ray W. SPEAR Department of Biology, University of New Brunswick, Fredericton, New Brunswick E3B 6E1 and Department of Biology, State University of New York at Geneseo,1 College Circle, Geneseo, New York 14454, U.S.A.

\begin{abstract}
The most recent paleoenvironmental change to affect the Yukon centres around $6.0 \mathrm{ka}$. In the forested southern Yukon, black spruce (Picea mariana) and green alder (Alnus crispa) expanded their populations at most sites between 6.5 and $6.0 \mathrm{ka}$. Even in the semi-arid region of SW Yukon these species increased their populations, although slightly later at 5.5 ka. These vegetation changes in the south imply cooler and wetter growing seasons, i.e. more mesic conditions. In the region of the upper Blackstone River of central $\mathrm{Yu}$ kon, the modern vegetation consists of shrub tundra with scattered groves of white spruce (Picea glauca) and even fewer black spruce. Open forests of predominantly white spruce occupied the region as early as $9.5 \mathrm{ka}$, but between 6.5 and 6.0 ka white spruce declined as black spruce became the dominant tree, coincidentally with an increase in green alder. By $5.0 \mathrm{ka}$ the vegetation had acquired its modern composition. As in the south, these changes imply cooling. Less evidence is available on the expansion of alder and black spruce in the northern $\mathrm{Yu}$ kon. Both species increased in forested areas (forest-tundra) at $6.0 \mathrm{ka}$. These changes again imply cooling. Because both black spruce and green alder were present in Yukon well before $6 \mathrm{ka}$, these vegetation changes cannot be ascribed to migration lags.
\end{abstract}

RÉSUMÉ Les changements apportés à la paléovégétation et au paléoclimat du Yukon à 6 ka BP. Au Yukon, les changements environnementaux les plus récents se sont produits vers $6 \mathrm{ka}$. Dans les zones forestières du sud du Yukon, l'épinette noire (Picea mariana) et l'aulne crispé (Alnus crispa) ont vu leur population augmenter entre 6,5 et 6 ka dans la plupart des sites. Même dans la région semi-aride du sud-ouest du Yukon, ces espèces ont connu une augmentation, bien qu'elle se soit produite plus tard, soit vers 5,5 ka. Ces changements dans la végétation méridionale du Yukon signalent l'avènement de saisons végétatives plus fraîches et plus humides, c'est-à-dire des conditions plus mésiques. Dans la région du cours supérieur de la Blackstone River, au centre du Yukon, la végétation moderne se compose d'une toundra arbustive parsemée ça et là de colonies d'épinettes blanches (Picea glauca) et de rares épinettes noires. Les forêts ouvertes dominées par l'épinette blanche peuplaient la région jusqu'à $9,5 \mathrm{ka}$, mais entre 6,5 et 6 ka, l'épinette blanche a décliné au profit de l'épinette noire, en concomitance avec une augmentation de l'aulne crispé. Vers $5 \mathrm{ka}$, la végétation avait acquis son caractère moderne. Tout comme au sud, ces changements impliquent un refroidissement. II existe moins d'indices quant à l'expansion de l'aulne et de l'épinette noire dans le nord du Yukon. Les deux espèces se sont répandues dans les zones forestières (toundra forestières) à 6 ka. Encore une fois, il dut y avoir refroidissement. Puisque l'épinette noire et l'aulne crispé étaient présents dans le Yukon bien avant $6 \mathrm{ka}$, on ne peut attribuer ces changements enregistrées par la végétation à des décalages migratoires.
ZUSAMMENFASSUNG Paläovegetation und paläoklimatische Veränderungen im Yukon um 6 ka v.u.Z. Die jüngsten Paläoumweltveränderungen im Yukon sind um etwa 6.0 ka geschehen. Im bewaldeten südlichen Yukon haben Schwarzfichte (Picea mariana) und grüne Erle (Alnus crispa) inre Population an den meisten Plätzen zwischen 6.5 und 6.0 ka erhöht. Selbst in der halbtrockenen Region von Südwest-Yukon haben diese Arten ihre Populationen erhöht, wenn auch etwas später, um $5.5 \mathrm{ka}$. Diese VegetationsWechsel im Süden weisen auf kühlere und feuchtere Wachstumszeiten, d.h. mehr mittlere Bedingungen. Im Gebiet des oberen Laufs des Blackstone River von ZentralYukon besteht die moderne Vegetation aus Busch-Tundra mit verstreuten Wäldchen von Weißfichte (Picea glauca) und noch weniger Schwarzfichte. Offene Wälder vor allem mit Weißfichte bevölkerten die Region so früh wie $9.5 \mathrm{ka}$, aber zwischen 6.5 und $6.0 \mathrm{ka}$ nahm die Weißfichte $a b$, während die Schwarzfichte der beherrschende Baum wurde, begleitet von einer Zunahme von grüner Erle. Um 5.0 ka hatte die Vegetation ihre moderne Zusammensetzung erreicht. Wie im Süden beinhalten diese Veränderungen eine Abkühlung. Über die Ausdehnung von Erle und Schwarzfichte im nördlichen Yukon gibt es weniger Belege. Beide Arten nahmen in bewaldeten Gebieten (Wald-Tundra) um 6.0 ka zu. Auch hier bedeuten die Wechsel eine Abkühlung. $\mathrm{Da}$ beide, Schwarzfichte und grüne Erle, lange vor $6 \mathrm{ka}$ im Yukon vorhanden waren, kann man diese Vegetationswechsel nicht Verzögerungen bei der Wanderung zuschreiben. 


\section{INTRODUCTION}

A dynamic period of vegetation and climate change occurred in the Yukon during the Late Pleistocene to early Holocene, so that by the middle Holocene most of the dominant trees and shrubs had become established, with the exception of lodgepole pine (Pinus contorta), which first entered Yukon about $5.5 \mathrm{ka}$ (MacDonald and Cwynar, 1991), and possibly also subalpine fir (Abies lasiocarpa) whose history is poorly known. Hansen and Engstrom's (1985) qualitative technique for identifying pollen of black and white spruce permits more refined reconstructions of vegetation and climate of the Yukon where these spruce species dominate forests. The application of this technique to a number of sites in recently published studies (Cwynar, 1988; Cwynar and Spear, 1991) and to two sites reported here for the first time, reveals significant changes in vegetation and climate in the Yukon between 6.5 and $5.5 \mathrm{ka}$. This paper summa- rizes the evidence of vegetation and climate change in the Yukon centered on $6.0 \mathrm{ka}$. The location of sites discussed is shown in Figure 1a.

\section{THE STUDY AREA}

\section{CLIMATE}

Yukon climate is sub-arctic continental with mean annual temperatures that decline with increasing latitude and are below $0^{\circ} \mathrm{C}$ in all areas (Fig. 1b). Climate and vegetation are strongly influenced by the rugged topography. The northern Rocky Mountains follow the eastern boundary of the territory and cut across the central Yukon as the Ogilvie Mountains, lowering temperatures there. The coastal mountains along the Alaskan panhandle extend into the Yukon, creating a pronounced rainshadow in the southwest Yukon (Fig. 1c). Parts of this region are technically semi-desert, receiving less than $250 \mathrm{~mm}$ of precipitation annually.
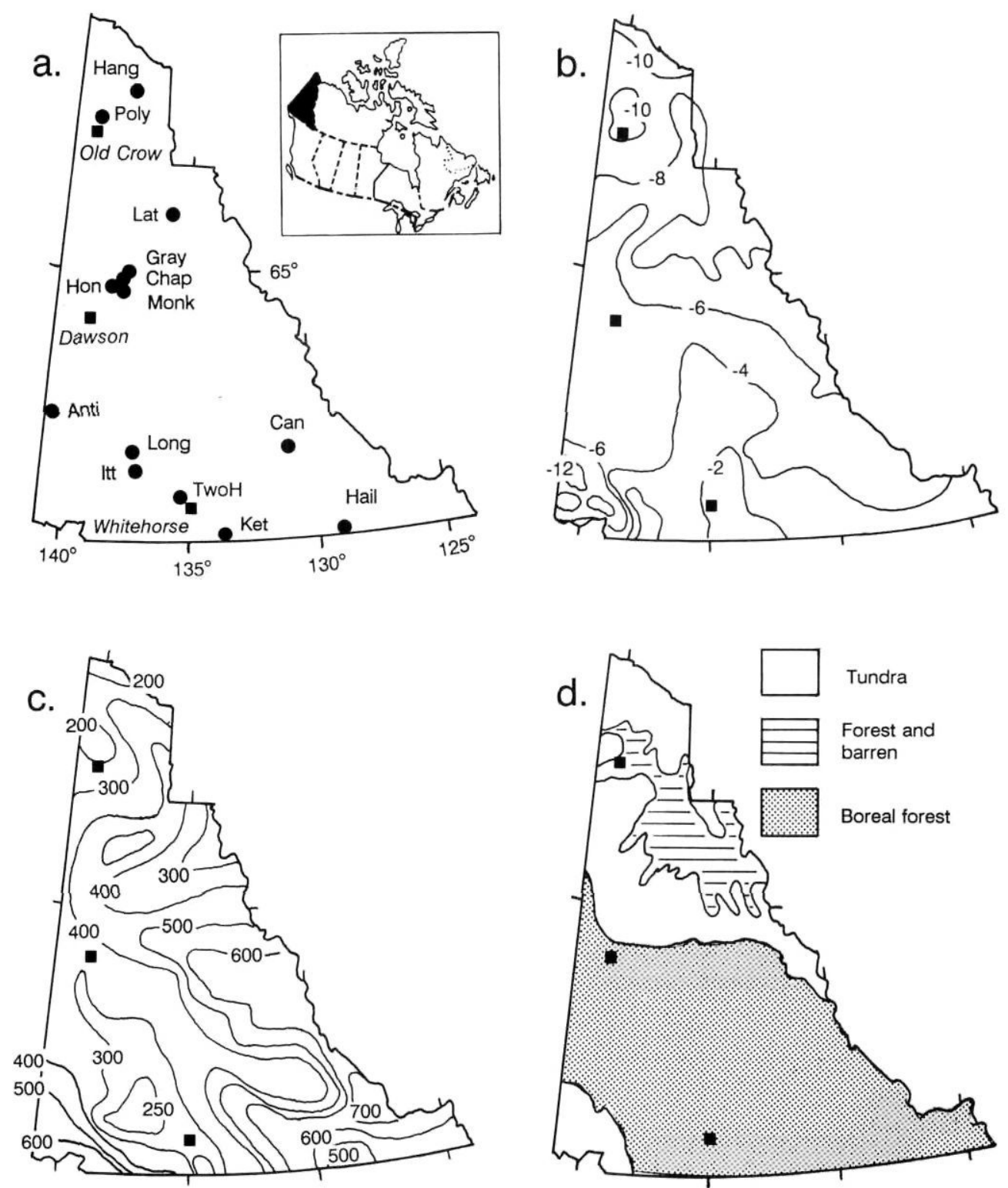

FIGURE 1. Maps of the Yukon showing: a) names of sites discussed in this paper. The designations are Anti (Antifreeze Pond), Can (Candelabra Lake), Chap (Chapman Lake), Gray (Grayday Pond), Hail (Hail Lake), Hang (Hanging Lake), Hon (Honeymoon Pond), Itt (Ittlemit Lake), Ket (Kettlehole Pond), Lat (Lateral Pond), Long (Long Last Lake), Monk (Monkshood Pond), Poly (Polybog), and TwoH (Two Horsemen Pond) (the three squares indicate towns as points of reference); b) mean annual temperatures in degrees Celcius, after Wahl et al. (1987); c) mean annual precipitation in $\mathrm{mm}$, after Wahl et al. (1987); d) vegetation zones after Rowe (1972).

Cartes du Yukon illustrant : a) les noms de lieux des sites dont il est question dans le texte. II s'agit de Anti (Antifreeze Pond), Can (Candelabra Lake), Chap (Chapman Lake), Gray (Grayday Pond), Hail (Hail Lake), Hang (Hanging Lake), Hon (Honeymoon Pond), Itt (Ittlemit Lake), Ket (Kettlehole Pond), Lat (Lateral Pond), Long (Long Last Lake), Monk (Monkshood Pond), Poly (Polybog), and TwoH (Two Horsemen Pond) (les trois carrés donnent l'emplacement de villes qui servent de points de référence); b) températures annuelles moyennes selon Wahl et al. (1987); c) précipitations annuelles moyennes selon Wahl et al. (1987); d) zones de végétation selon Rowe (1972). 


\section{VEGETATION}

The southern half of the Yukon is covered for the most part with closed boreal forest (Fig. 1d). In the southeast, boreal forests are the commercially most productive in the Yukon. Trembling aspen (Populus tremuloides), lodgepole pine (Pinus contorta), white (Picea glauca) and black (Picea mariana) spruce, and white birch (Betula papyrifera) are all common. Balsam poplar (Populus balsamifera) and larch (Larix laricina) are minor forest constituents. In the drier west, however, forests may be open at low elevations. Trembling aspen and white spruce dominate these forests, whereas black spruce, larch, and white birch are uncommon, and lodgepole pine is absent all together from the westernmost forests. At high elevations throughout the southern Yukon, subalpine fir (Abies lasiocarpa) is common and often dominant. The central Yukon is a mountainous region of shrub tundra with scattered groves of spruce, generally white. Open boreal forest grows north of the central Yukon where black spruce is especially prominent. The northernmost Yukon supports low arctic tundra.

\section{Study Sites}

Data from two of the sites discussed in this summary paper have not been previously published. They are described here under informal appellations.

Hail Lake is located near the junction of the Alaska and Cassiar Highways at $60^{\circ} 02^{\prime} \mathrm{N}, 129^{\circ} 01^{\prime} \mathrm{W}$ at an elevation of $690 \mathrm{~m}$ asl. The 1.0 ha closed basin lake was cored at a water depth of $7.39 \mathrm{~m}$. Black and white spruce dominate the closed forests immediately around the lake and lodgepole pine, white birch, and trembling aspen are of minor importance. Outside the drainage basin lodgepole pine dominates the forests.
Candelabra Lake is located along the Robert Campbell Highway at $61^{\circ} 41^{\prime} \mathrm{N}, 130^{\circ} 39^{\prime} \mathrm{W}$ at an elevation of $1040 \mathrm{~m}$ asl. It is approximately 5 ha with a maximum water depth of $2.96 \mathrm{~m}$. Black spruce dominates the watershed, in the extensive muskeg along the north, east, and west sides of the lake, and in the low hills on the south side. No pine occurs within the watershed.

Coring and analysis of these sites followed standard procedures outlined elsewhere (Cwynar and Spear, 1991). Because this paper focuses on $6 \mathrm{ka}$, we do not present complete results or pollen diagrams. Details for all pollen taxa and ${ }^{14} \mathrm{C}$ dating at Hail and Candelabra Lakes will be provided in a later paper. However, as the chronology of the sites is important to the discussion, we note that for Hail Lake it is based on 11 accelerator-mass spectrometer ${ }^{14} \mathrm{C}$ dates of terrestrial macrofossils (three basal dates $>30 \mathrm{ka}$ rejected), and for Candelabra it is based on 11 conventional dates of bulk sediment and the eastern lobe of the White River tephra (1.25 ka, Lerbekmo et al., 1975).

\section{REGIONAL VEGETATION CHANGES}

\section{SOUTHEAST YUKON}

At Hail Lake (Figs. 2 and 3) white spruce populations expanded at $9.1 \mathrm{ka}$ and dominated the forests until $6.0 \mathrm{ka}$. High intial percentages (maximum about $40 \%$ ) and PARs (pollen accumulation rates; >2000 grains $/ \mathrm{cm}^{2} / \mathrm{yr}$ ) for black spruce indicate that it was locally present early in the Holocene. However, black spruce became dominant, reaching values of $60 \%$ of total pollen, only after $6.0 \mathrm{ka}$. Black spruce percentages and PARs peak between 6.0 and 5.1 ka, but then fall as lodgepole pine increases. Green alder percentages and PARs increase coincidentally with the rise in black spruce at $6.0 \mathrm{ka}$.

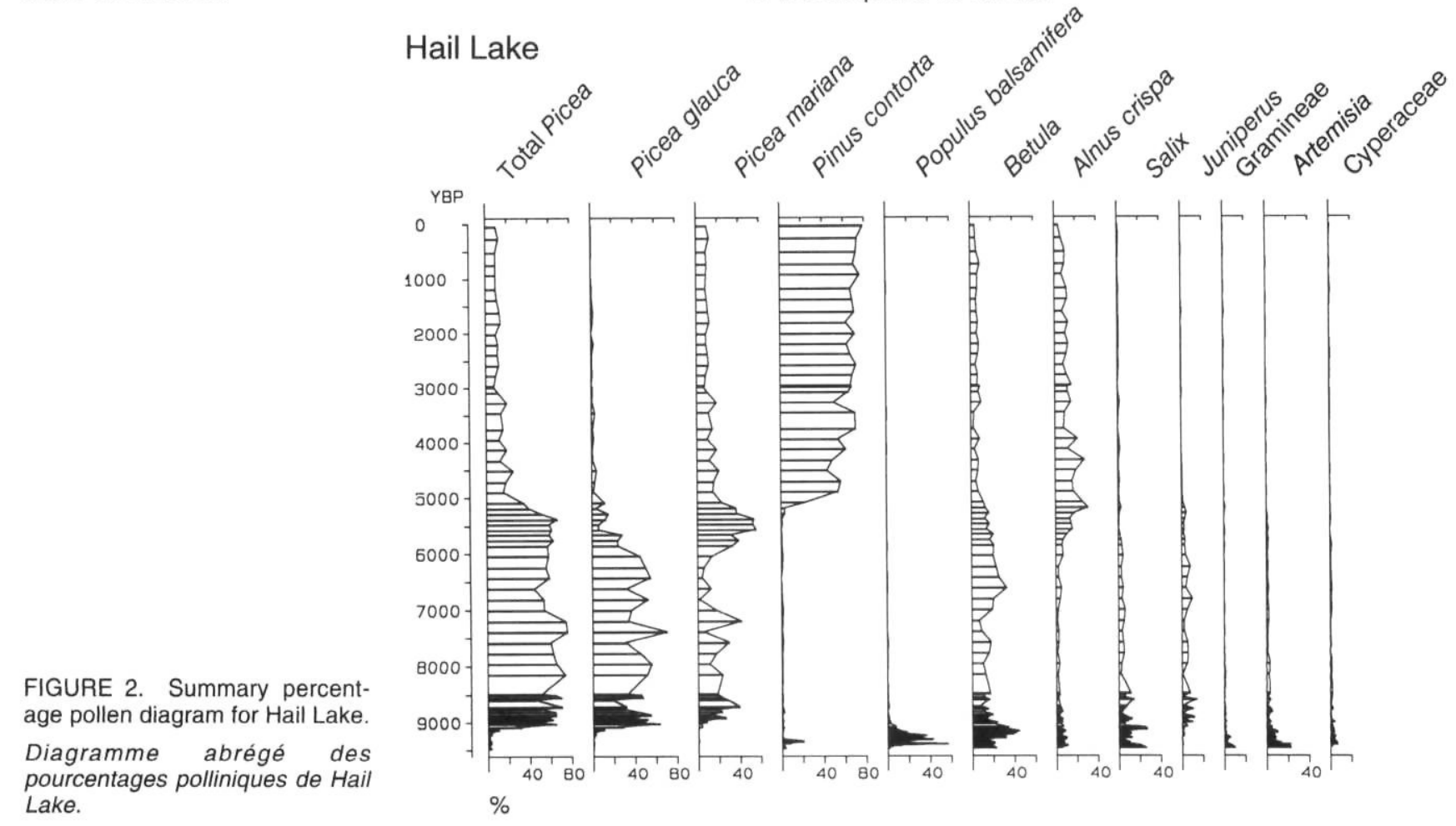




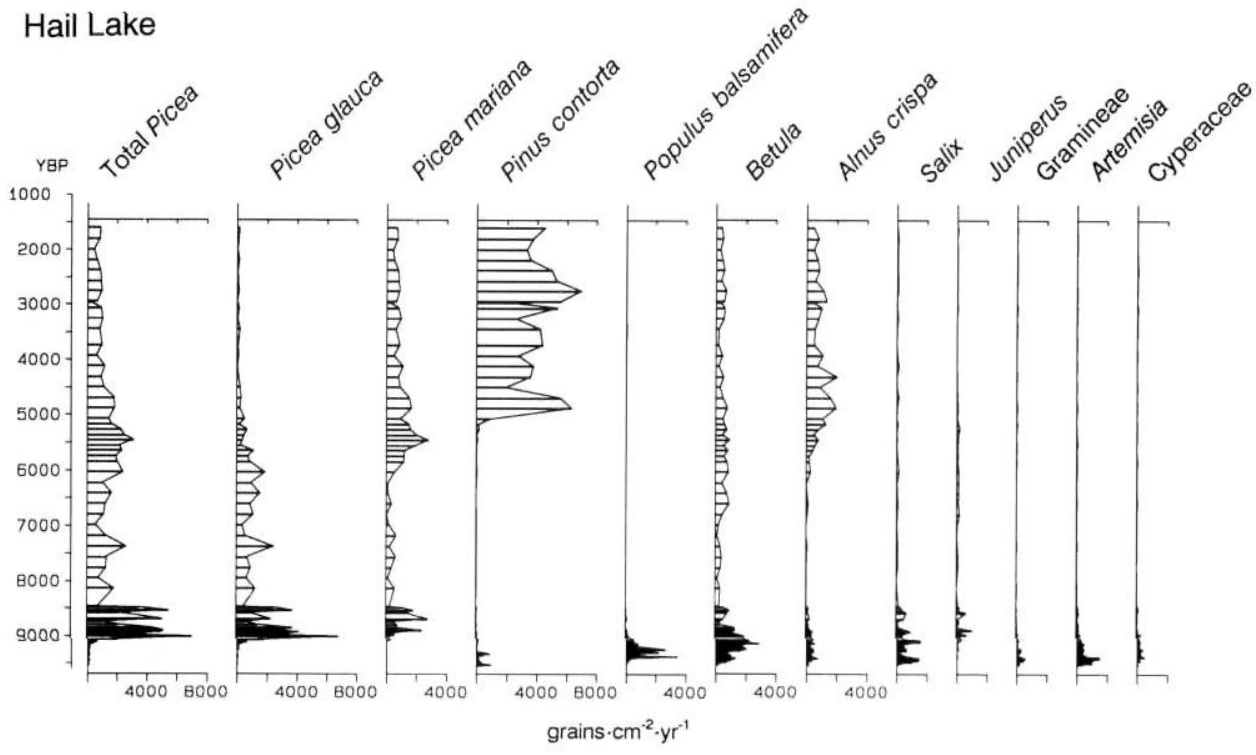

FIGURE 3. Summary pollen accumulation rate diagram for Hail Lake.

Diagramme abrégé des taux d'accumulation pollinique de Hail Lake.

At Candelabra (Figs. 4 and 5) white spruce populations increased at 9.2 ka followed shortly afterward by black spruce. In contrast with Hail, with the exception of a brief initial dominance by white, black spruce was the dominant species for most of the early Holocene. Both percentages and PARs show increases in black spruce at 8.5 and $6.3 \mathrm{ka}$ at the expense of white, but at 6.3 black spruce percentages and PARs increase to their maximum Holocene values, peaking at $6.0 \mathrm{ka}$. Green alder does not show a sharp increase coincident with this rise in black spruce. Instead, it shows a gradual increase between 7.0 and $5.0 \mathrm{ka}$, and its largest increase at $5.0 \mathrm{ka}$.

In summary, these two sites both show increases in black spruce at or just prior to $6.0 \mathrm{ka}$ at the expense of white spruce. Because both species had been present during the preceding $3.0 \mathrm{ka}$, the changes in their relative abundances most likely result from climate change at $6.0 \mathrm{ka}$. As black spruce generally grows on cooler and moister sites than white spruce, we conclude that climate must have become cooler, increasing effective moisture (difference between precipitation and evaporation). At Hail, the coincident increase in green alder, a plant of moist habitats, supports the interpretation of increased effective moisture. The rise in green alder is more subdued at Candelabra, probably because dwarf birches and heaths predominate in the extensive muskeg around the lake which is not good habitat for alder.

\section{SOUTHWEST}

The most striking middle Holocene changes in the SW Yukon occur at Kettlehole Pond (Cwynar, 1988), which lies in coarse glacio-fluvial outwash at the margin of the semiarid region (Fig. 1c). At 6.1 ka pollen assemblages (Fig. 6) dominated by white spruce (40-60\%) and juniper (10-40\%) are suddenly replaced by assemblages dominated by black spruce $(40 \%)$. These relative changes are reflected in PARs (not shown). Black spruce remains dominant until $4.1 \mathrm{ka}$, then declines in two steps to its modern negligible values. The predominance of black spruce between 6.1 and $4.1 \mathrm{ka}$ is remarkable because it is completely absent from the modern vegetation of the valley bottom in which Kettlehole sits. Clearly their must have been a significant increase in effective moisture at $6.1 \mathrm{ka}$ as open forest with white spruce and juniper indicative of a dry climate was replaced by a more mesophytic black spruce woodland. Green alder percentages and PARs increase only slightly at 6.1; a larger rise in PARs occurs at $4.9 \mathrm{ka}$. The abundance of green alder pollen $(40 \%)$ from the beginning of the record at $11.0 \mathrm{ka}$ demonstrates that it was present in the southern Yukon quite early.

At Long Last Lake, white spruce is the dominant species of spruce beginning with its arrival at $8.5 \mathrm{ka}$ (Keenan and Cwynar, 1992). Black spruce is a minor component throughout the record, showing an initial rise at $8.0 \mathrm{ka}$ to $5-10 \%$ and then another increase in percentage and PARs to maximal values (about 10\%) between 5.4 and 3.9 ka which is accompanied by a decline in white spruce. Green alder also begins to increase at $5.4 \mathrm{ka}$. Similar trends can be seen at nearby Two Horsemen Pond, but they are undated (Keenan and Cwynar, 1992).

Wang and Geurts (1991a) cored a peatland near the northwestern end of Ittlemit Lake in the semi-arid zone. Alnus pollen, presumably green alder, increased at $5.0 \mathrm{ka}$ simultaneously with a large increase in sedge pollen and a change in sediment lithology from organic silt to peat. The authors concluded that soil moisture must have increased. Spruce provides no support for this conclusion because the grains were not identified to species.

Wang and Geurts (1991b) presented a comprehensive review of late Quaternary vegetation history of the southwest Yukon that included data from new sites in the Aishihik basin (general vicinity of Long Last Lake). Percentages of alder were low, generally less than $10 \%$, throughout the Holocene in the region and alder is rare on the modern landscape. Although no consistent changes can be seen in the pollen records of the Aishihik basin, pond $\mathrm{XW}-4$ became a marsh or bog at $5.9 \mathrm{ka}$ and at Moose Depression (XW-6) 


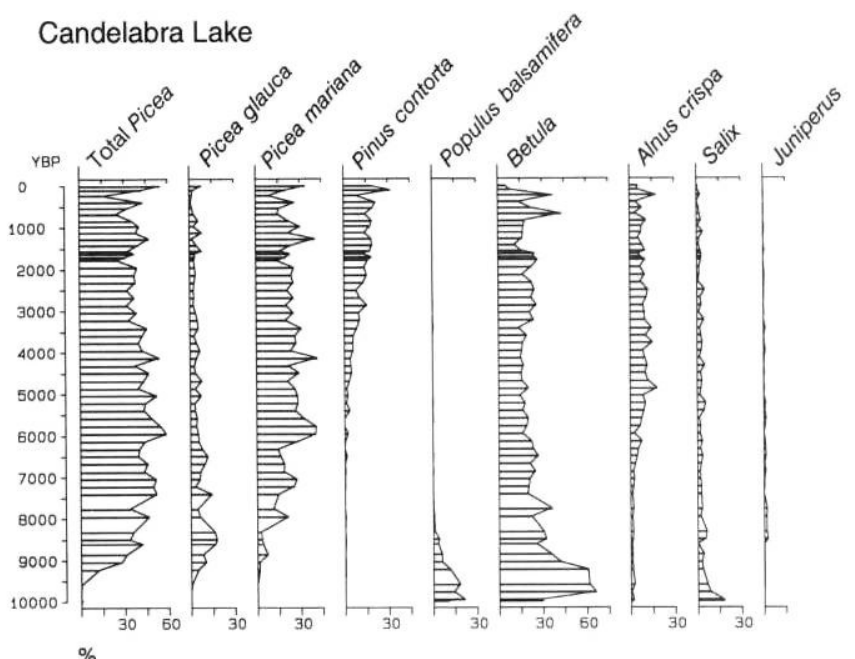

FIGURE 4. Summary percentage pollen diagram for Candelabra Lake.

Diagramme abrégé des pourcentages polliniques de Candelabra Lake.

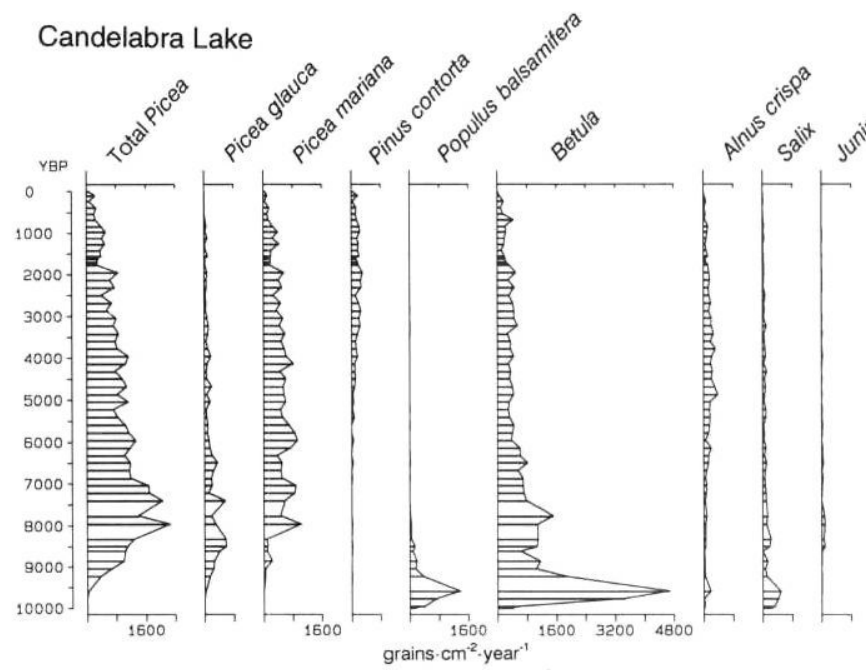

FIGURE 5. Summary pollen accumulation rate diagram for Candelabra Lake.

Diagramme abrégé des taux d'accumulation pollinique de Candelabra Lake.

the lithology changed from pond sediment to peat at $5.7 \mathrm{ka}$. The climatic significance of these lithologic changes is not entirely clear. The cessation of lake sediment accumulation may have resulted from increased aridity. However, the initiation of peat deposition may imply an increase in moisture. Without a detailed understanding of the development of these basins based on multiple cores across the sites, the climatic significance of these changes cannot be determined.

Wang and Geurts (1991b) remarked that "it is worthwhile to note the change of pollen composition around $6000 \mathrm{yr}$ BP" in Yukon and adjacent Alaska and Northwest Territories. For the southern Yukon they mentioned the changes at Kettlehole Pond, (described earlier) and at Antifreeze Pond (Rampton, 1971). The latter site is located in the Snag-Klutlan area near the Alaska-Yukon border. The area

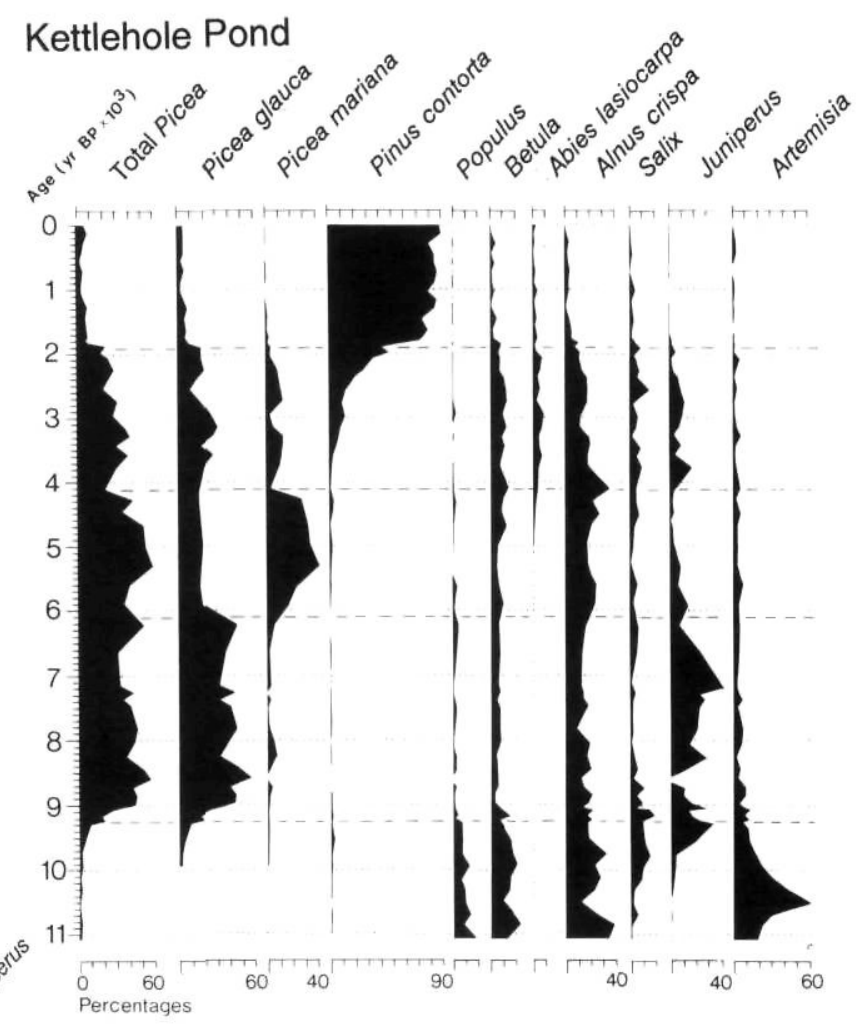

FIGURE 6. Summary percentage pollen diagram fo Kettlehole Pond.

Diagramme abrégé des pourcentages polliniques de Kettlehole Pond.

is outside the rainshadow of the coastal mountains and black spruce dominates the vegetation below treeline. At $5.7 \mathrm{ka}$ alder pollen, presumably Alnus crispa, rises sharply and spruce increases from about 20 to $30 \%$, although its identity is unknown as the techniques for separating black and white spruce had not yet been developed.

In summary, the driest portions of southwest Yukon, e.g. Aishihik area, appear to have been inhospitable to alder throughout the Holocene and no significant changes at 6.0 ka are discernable from the pollen records. Peat accumulation may also have been initiated at some semi-arid sites at this time, although the climatological significance of this development is not clear. Sites on the periphery of the semi-arid region (Kettlehole Pond) or outside of it (Antifreeze Pond) show large increases of either black spruce or alder pollen at about $6.0 \mathrm{ka}$, implying greater available moisture.

\section{CENTRAL YUKON}

The central Yukon is transected by westward extensions of the Mackenzie Mountains, resulting in a broad belt of shrub tundra between closed boreal forest to the south and forest tundra to the north. Isolated stands of white spruce and occasionally black spruce are scattered throughout the shrub tundra. Three sites studied by Cwynar and Spear (1991) were forested early in the Holocene. At all three a middle Holocene white spruce decline and black spruce increase coincide with a rise in green alder; the percentage 
pollen diagram from Honeymoon Pond is given as a typical example (Fig. 7). These changes date from $6.0 \mathrm{ka}$ at Grayday Pond, $6.5 \mathrm{ka}$ at Monkshood Pond, to $6.7 \mathrm{ka}$ at Honeymoon Pond, for an area average of $6.4 \mathrm{ka}$. Because black spruce typically grows on colder and wetter sites than white spruce, we conclude that the changes at $6.4 \mathrm{ka}$ signal a cooling of climate, possibly attended by an increase in available moisture. It is especially clear from the macrofossil records of these sites that the cooling trend continued and forest gave way to the modern shrub tundra by $5.0 \mathrm{ka}$. Another pollen diagram from the region, near Chapman Lake, also shows a middle Holocene rise in alder but it is undated (Terasmae and Hughes, 1966).

\section{NORTHERN YUKON}

Ritchie (1982) reported in detail the analysis of pollen from sediments of Lateral Pond, which lies between lateral moraines in the valley of Doll Creek in the southern Richardson Mountains. Both percentages and PARs reveal increases in green alder at $6.0 \mathrm{ka}$. Spruce values also show a significant increase at this time, but the analysis predates techniques for identifying grains to species. Tyrrell Lake in the same region shows similar patterns (Ritchie, 1982).

Ovenden (1982) obtained a peat core from a site named Polybog, a broad polygonal peat plateau at the southern margin of the Old Crow Flats. Percentages of green alder first begin to increase at $6.7 \mathrm{ka}$, although the PARs indicate that the main rise occurs later at about $5.8 \mathrm{ka}$. According to macrofossil evidence, spruce had become established locally by $8.5 \mathrm{ka}$. At $5.7 \mathrm{ka}$, when green alder was increasing, black spruce macrofossils became consistently present in the peat. The presence of Sphagnum fuscum and black spruce between 5.7 and 5.3 ka suggested a period of dryness and possibly increased warmth. It is not clear whether these changes result from changes in climate or local edaphic/topographical changes.

At Hanging Lake, which is northeast of the Old Crow Flats, there are no palynological changes associated with $6.0 \mathrm{ka}$ (Cwynar, 1982). A sharp rise in green alder occurs at $8.9 \mathrm{ka}$, but the sediments are inorganic ( $<15 \% \mathrm{LOI})$ and the dates may be too old. Combined with the fact that green alder does not grow at Hanging Lake today, we are inclined to accept the peat dates and pollen stratigraphy at Polybog in the adjacent Old Crow Flats.

In summary, green alder and spruce both increased in forested regions of the northern Yukon at about $6.0 \mathrm{ka}$. At Polybog it was black spruce that increased at $5.7 \mathrm{ka}$. The one site in tundra, Hanging Lake, shows no palynological changes associated with $6.0 \mathrm{ka}$, although the dates there are likely too old.

\section{CONCLUSIONS}

With the exception of the most arid parts of southwest Yukon, green alder and spruce both increased in abundance throughout the region between 6.5 and $6.0 \mathrm{ka}$. The middle Holocene increase of green alder has attracted considerable interest, and various hypotheses for its spread have been proposed (Hopkins et al., 1981; Ritchie, 1984). In a prescient observation, Ritchie (1984) wrote of the northern part of the region "...if the early palynological intimations ... that the early Holocene spruce forests were predominantly white spruce communities and that black spruce became more important later, prove to represent a general phenomenon, then hypotheses are likely that suggest widespread edaphic changes, possibly stimulated by cooler moister climates, promoting paludification and rising permafrost tables. Such reconstructions might well also accomodate the alder pollen data...". Keenan and Cwynar

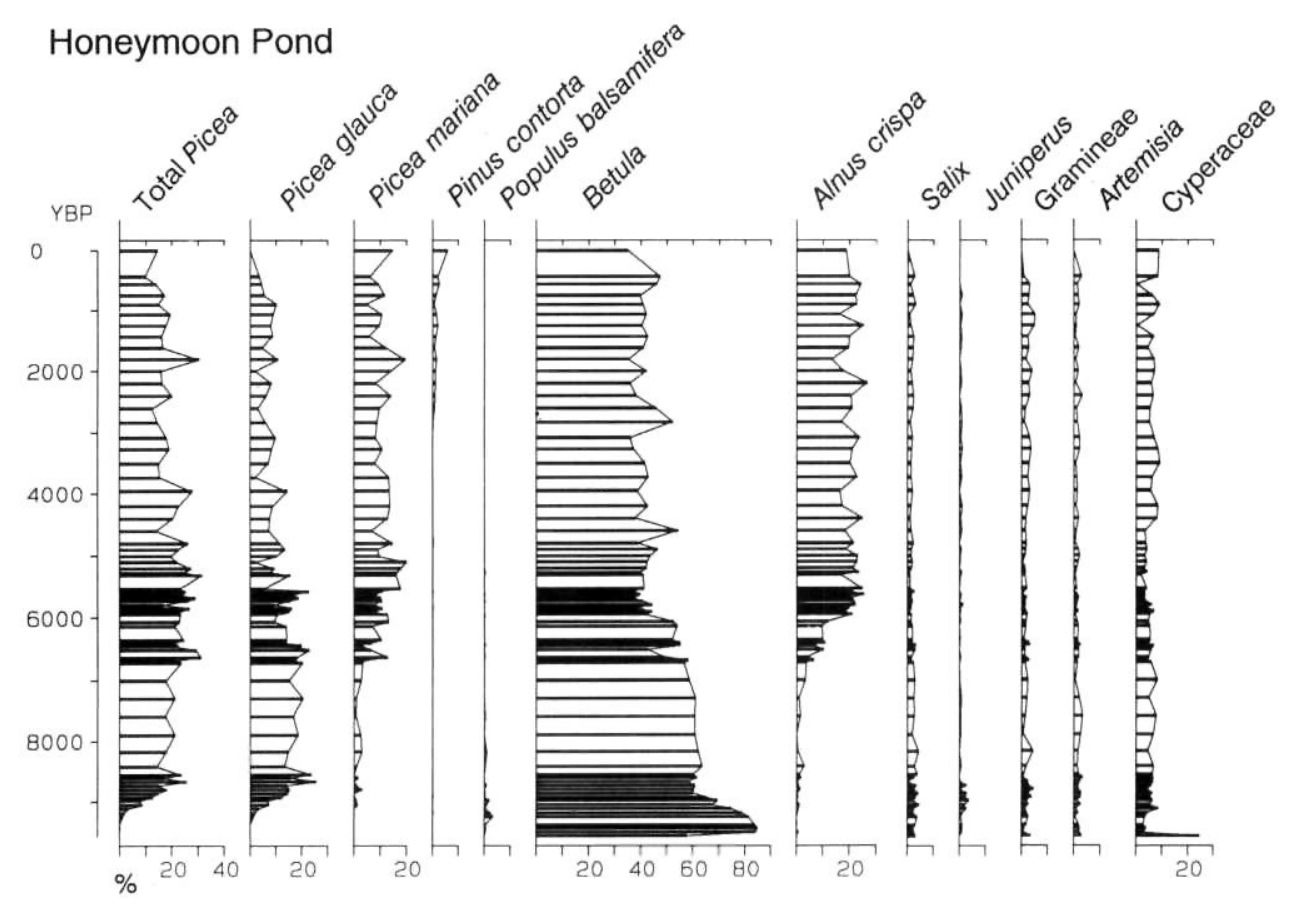

FIGURE 7. Summary percentage pollen diagram for Honeymoon Pond.

Diagramme abrégé des pourcentages polliniques de Honeymoon Pond. 
(1992) made just this argument for the southwest Yukon following Ritchie's (1984) lead. In the semi-arid southwest Yukon the increases of green alder and black spruce clearly signal moister conditions developing at $6.0 \mathrm{ka}$. It is important to note that green alder was already present in the southern Yukon early in the Holocene, e.g. at low elevation sites such as Kettlehole Pond and mid-elevation sites, such as Fir Lake near Carcross where it reached values of $50 \%$ (Cwynar and Spear, unpublished). The failure of green alder to expand its populations or to spread to other parts of the region until much later suggests that climate was unfavourable, likely due to aridity. However, at the higher elevations of the central Yukon, these same changes in green alder and spruce suggest cooling, a trend which continued as black spruce then gave way to the modern shrub tundra by $5.0 \mathrm{ka}$. In conclusion, it appears that green alder and black spruce increased throughout most of the Yukon between 6.5 and $5.4 \mathrm{ka}$, implying cooler and moister conditions.

\section{ACKNOWLEDGEMENTS}

Authors are grateful to reviewers Robert $\mathrm{J}$. Mott and John V. Matthews for their useful comments.

\section{REFERENCES}

Cwynar, L.C., 1982. A Late-Quaternary vegetation history from Hanging Lake, northern Yukon. Ecological Monographs, 52: 1-24.

- 1988. Late Quaternary vegetation history of Kettlehole Pond, southwestern Yukon. Canadian Journal of Forest Research, 18: 1270-1279.

Cwynar, L.C. and Spear, R.W., 1991. Reversion of forest to tundra in the central Yukon. Ecology, 72: 202-212.

Hansen, B.C.S. and Engstrom, D.R., 1985. A comparison of numerical and qualitative methods of separating pollen of black and white spruce. Canadian Journal of Botany, 63: 2159-2163.
Hopkins, D.M., Smith, P.A. and Matthews Jr., J.V., 1981. Dated wood from Alaska and the Yukon: implications for forest refugia in Beringia. Quaternary Research, 15: 217-249.

Keenan, T.J. and Cwynar, L.C., 1992. Late Quaternary history of black spruce and grasslands in southwest Yukon Territory. Canadian Journal of Botany, 70: 1336-1345.

Lerbekmo, J.F, Westgate, J.A., Smith, D.G.W. and Denton, G.H., 1975. New data on the character and history of the White River volcanic eruption, Alaska, p. 203-209. In R.P. Suggate and M.M. Cresswell, eds., Quaternary Studies. Proceedings of IX Congress, International Union for Quaternary Research, The Royal Society of New Zealand, Wellington,

MacDonald, G.M. and Cwynar, L.C., 1991. Post-glacial population growth rates of Pinus contorta ssp. latifolia in western Canada. Journal of Ecology, 79: 417-429.

Ovenden. L., 1982. Vegetation history of a polygonal peatland, northern Yukon. Boreas, 11: 209-224.

Rampton, V., 1971. Late Quaternary vegetational and climatic history of the Snag-Klutlan area, south-western Yukon Territory, Canada. Geological Society of America Bulletin, 88: 959-978.

Ritchie, J.C., 1982. The modern and late-Quaternary vegetation of the Doll Creek area, north Yukon, Canada. New Phytologist, 90: 563-603.

1984. Past and present vegetation of the Far Northwest of Canada. University of Toronto Press.

Rowe, J.S., 1972. Forest regions of Canada. Canadian Forest Service Publication No. 1300.

Terasmae J. and Hughes, O.L., 1966. Late Wisconsinan chronology and history of vegetation in the Ogilvie Mountains, Yukon Territory, Canada. The Palaeobotanist, 15: 235-242.

Wahl, H.E., Fraser, D.B., Harvey, R.C. and Maxwell, J.B., 1987. Climate of Yukon. Atmospheric Environment Service, Climatological Studies No. 40. Environment Canada, Ottawa.

Wang, X.-C. and Geurts, M.-A., 1991a. Post-glacial vegetation history of the Ittlemit Lake Basin, southwest Yukon Territory. Arctic, 44: 23-30.

1991b. Late Quaternary pollen records and vegetation history of southwest Yukon Territory: A review. Géographie physique et Quaternaire, 45: 175-193. 